\title{
«Det har sine omkostninger». Spesialpedagogens trivsel og belastninger $i$ arbeidet $i$ en inkluderende skole: En intervjustudie.
}

\author{
Marit Uthus* \\ NTNU - Norges teknisk-naturvitenskapelige universitet
}

\section{SAMMENDRAG}

Både i Norge og andre nordiske land har det blitt vist til ideologiske taktskifter i utdanningssystemet, der mål om inkludering må vike for kravet om en mer kunnskapseffektiv skole. Vi vet lite om hvordan spesialpedagoger erfarer arbeidet sitt stilt overfor disse endringene. I denne studien ble elleve spesialpedagoger dybdeintervjuet med åpne intervjuspørsmål om arbeidet sitt i norsk grunnskole, med særlig fokus på spesialundervisningen og praktiseringen av denne. De sentrale funnene i studien viste at spesialpedagogenes opplevelser av trivsel i arbeidet lot seg forklare med bakgrunn i tre dimensjoner: En verdidimensjon, en dimensjon av spesialpedagogisk kompetanse, og en dimensjon av nærhet til elever med særskilte behov. Når disse dimensjonene ble utfordret av målstyrte prinsipper for utdanning, erfarte spesialpedagogene til dels store belastninger. Dermed argumenteres det for fornyet tillit og bedre arbeidsvilkår for spesialpedagoger, slik at de kan realisere sine ambisjoner om å være inkluderingsagenter i en skole ment for alle elever.

\section{Nøkkelord: Spesialpedagoger; inkluderende skole; trivsel; belastninger}

\section{ABSTRACT "It has its costs"}

Both in Norway and other Nordic countries, it has been shown ideological changes in the education system, where the goal of inclusion must give way to the demand for a more knowledge-effective school. We know little about how special educators experience these changes. In this study, eleven special educators were interviewed about their work-experiences in the Norwegian public elementary school system. The searchlight was aimed at their experiences with special education and the practice of this. The central findings in the study showed that the special educators' experiences of job satisfaction were explained based on three mutually dependent dimensions: A value dimension, a professional dimension, and a dimension of proximity to the students with special needs. When goal-oriented principles of education challenged the three dimensions, special educators sometimes experienced great stress. On this basis, increased trust and better working conditions for special

^Korrespondanse: Marit Uthus, epost: marit.uthus@ntnu.no

(C) 2019 Marit Uthus. This is an Open Access article distributed under the terms of the Creative Commons Attribution 4.0 International License (https://creativecommons.org/licenses/by-nc/4.0/), allowing third parties to copy and redistribute the material in any medium or format and to remix, transform, and build upon the material for any purpose, even commercially, provided the original work is properly cited and states its license. 
educators are argued, so that they can realize their ambitions of being inclusion agents in a school meant for all students.

Keywords: Special educators; inclusive school; well-being; stress

Mottatt: September, 2018; Antatt: Oktober, 2019; Publisert: February, 2020

\section{Introduksjon}

Den inkluderende skolen har en ideologisk forankring i nasjoner verden over, med mål om å forebygge sosial ekskludering og marginalisering av sårbare grupper. Særlig vises det til at inkludering handler om noe mer og annet enn at alle barn skal ha rett til utdanning (Ainscow \& César, 2006): Det er retten til å være forskjellig som fremheves, og hovedpilarene som pekes ut er muligheten til å ta del i fellesskapet og ha utbytte av opplæringen, uavhengig av rase, religion, kjønn eller evner. Med Salamanca-erklæringen (UNESCO, 1994), signert av hele 92 land i 1994, markeres en ambisjon om å gi alle barn og unge tilfredsstillende opplæring innenfor den ordinære skolen. Det handler om å verdsette menneskelig mangfold, som forutsetning for et mer rettferdig samfunn. Videre vises det til at det er barn og unges muligheter og potensialer som skal stå i fokus, heller enn deres begrensinger og utfordringer.

I Norge er inkludering nedfelt som en lovbestemt rett til tilpasset opplæring innenfor skolens ordinære ramme (Opplæringslova $\ 2-1, \sqrt{\int} 8-1$ og $\ 1-3$ ). Ved å spesifisere at retten til spesialundervisning kun gjelder hvis eleven ikke har tilfredsstillende utbytte av det ordinære opplæringstilbudet (Opplæringslova \5-1), er det fra statlig hold lagt sterke føringer for å forstå inkludering som en tilpasset eller differensiert praksis som foregår i klasserommene, der elevmangfoldet oppholder seg. Samtidig fremheves det at kommuner og skoler skal forsøke å redusere omfanget av spesialundervisning, ment som et tiltak for å øke inkluderingen (Kunnskapsdepartementet, 2010-11; Kunnskapsdepartementet, 2012-2013). Dette perspektivet er også gitt støtte i det spesialpedagogiske fagfeltet (Bachmann \& Haug, 2006), på den måten at det vises til et omvendt proporsjonalt forhold mellom ordinær undervisning og spesialundervisning. Tanken er at jo mer den ordinære undervisningen blir tilpasset elevmangfoldet, jo mindre vil behovet for spesialundervisning være. Med målet om inkludering har det med andre ord fulgt en lang og sterk tradisjon for systemorienterte føringer for spesialpedagogenes arbeid (Kunnskapsdepartementet, 2010-11; Kunnskapsdepartementet, 2012-2013).

Både i Norge og andre nordiske land har idealet om en inkluderende skole hatt en klar utdanningspolitisk forankring. Dette må ses i lys av at sosialdemokratiske verdier som en sterk tro på fellesskapet og bærekraft gjennom gode velferdsordninger fikk stor oppslutning i disse landene i etterkrigstiden (Arnesen \& Lundahl, 2006). Likevel har det i de senere årene blitt stilt spørsmålstegn ved om nordiske land, i likhet med andre vestlige land, også bærer preg av et ideologisk taktskifte på samfunnsnivå; fra en sterk forpliktelse på enhetsskolen, mot at skolen regnes som den viktigste investeringen for nasjonenes effektivitet og konkurranseevne i det globale markedet (Imsen, Blossing \& Moos, 2017). 


\section{Marit Uthus}

Utdanningsforskning underbygger dette taktskiftet på den måten at elever som mottar spesialundervisning synes å utgiøre en nedprioritert og marginalisert elevgruppe i skolen (Uthus, 2014; Wendelborg, 2014; 2017). I Barneombudets (2017) rapport om spesialundervisning i grunnskolen avdekkes det at elever plasseres $i$ «tilfeldige oppbevaringsgrupper», at målene for opplæringen er uklare og innholdet likeså. Grunnskolens informasjonssystem [GSI] (Utdanningsdirektoratet, 2018a), bekrefter bildet: Ca. $50 \%$ av elevene som får spesialundervisning etter enkeltvedtak får opplæring av assistenter, og stadig flere elever faller utenfor skolens ordinære opplæring. Dette er bekymringsfullt særlig med tanke på at tallene ser ut til å stige fra år til år (Vedvik, 2018).

Situasjonen som tegnes tyder på at det er et gap mellom idealer og realiteter hva angår inkludering, tilpasset opplæring og spesialundervisning i norsk grunnskole. Dette er bakgrunnen for at utdanningspolitiske myndigheter etterlyser nye svar hva angår en mer inkluderende spesialpedagogisk praksis. I så måte har rapporten til Ekspertgruppen for barn og unge med behov for særskilt tilrettelegging (Nordahl, 2018) utløst en konstruktiv diskurs i fagfeltet om $h v a$ de konkrete svarene bør være (Uthus, 2018a; 2018b).

Det eksisterer med andre ord mange spørsmål og få klare svar hva angår spesialpedagogenes rolleutforming og praksis i grunnskolen. I denne studien var det dermed et mål å belyse hvordan uklare og kanskje også motsetningsfylte rolleforventninger kan gi seg utslag for spesialpedagogene og deres arbeid i grunnskolen, der de har ansvar for elever med rett til spesialundervisning etter enkeltvedtak.

\section{Tidligere forskning på spesialpedagoger}

Selv om de nordiske landene har til felles at utdanning anses som et velferdsgode som skal komme hele befolkningen til gode, har likevel idealet om inkluderende opplæring blitt oppfattet og praktisert ulikt fra land til land. I tråd med dette viser forskningen til ulike fokus for spesialpedagogens rolle og praksis i de ulike landene (Cameron \& Lindqvist, 2014; Cameron, Tveit, Jortveit, Lindqvist, Göransson \& Nilholm, 2018), men også innad i det enkelte land (Gillespie, 2016; Mjøs, 2007). Dette underbygger en antagelse om uklare rammer knyttet til yrkesutøvelsen for spesialpedagoger i skolen i dag.

Når det kommer til forskning der spesialpedagogene selv er deltakere, har denne i stor grad blitt gjennomført som surveys med fokus på hvorvidt deres holdninger til egen rolle og praksis er i tråd med systemorienterte føringer for inkludering, noe som bekreftes (Göransson, Lindqvist, Möllås, Almqvist \& Nilholm, 2017; Göransson, Lindqvist \& Nilholm, 2015; Lindqvist, Nilholm, Almqvist \& Wetso, 2011).

Det foreligger få studier som undersøker spesialpedagogenes egne subjektive perspektiver og erfaringer i arbeidet. Den forskningen som finnes viser til at det er uklart for spesialpedagogene hvilken rolle og praksis som er ment for dem i en inkluderende skole, samt at de erfarer at de erstattes av andre yrkesgrupper (Magnússon 
\& Göransson, 2018; Uthus, 2014). Slik Cameron og Tveit (2015) viser til, utgjør uklarhetene omkring spesialpedagogenes rolle den aller største utfordringen for spesialpedagogenes yrkesutøvelse, ikke bare knyttet til hvilken plass de skal ha, men like mye om de i det hele tatt skal ha en plass i den norske offentlige grunnskolen. Spesialpedagogene selv formidler at de ønsker å bidra til inkludering for elever med særskilte behov (Groven, 2007; Mjøs, 2007; Uthus, 2014), mens andre yrkesgrupper forventer av dem at de tar ansvar for elevene på et individuelt plan (Göranson et al., 2015; Lindqvist, 2013; Lindqvist et al., 2011; Uthus, 2014). Dette bekreftes i en reviewstudie som viser at lærere har nøytrale eller negative holdninger til inkludering for elever med særskilte opplæringsbehov (De Boer, Pijl \& Minnaert, 2011). Slike holdninger hos lærere må forstås i lys av det økte presset som de kan oppleve om å oppnå gode læringsresultater for elevene (Mausethagen, 2013), med dertil begrenset handlingsrom til å ta reelt medansvar for elever med særskilte behov. Problemet for spesialpedagogene er at dette gir seg utslag i belastninger på den måten at de opplever å stå alene om sine ambisjoner for elever med særskilte behov, samt av å ha lav status sammenlignet med andre yrkesgrupper i skolen (Göranson et al., 2015; Lindqvist et al., 2011; Magnússon \& Göransson, 2018; Uthus, 2014). Gillespie (2016) viser til at ordinær undervisning og spesialundervisning kan eksistere som to atskilte enheter i skolen, på den måten at det ikke finnes verken rutiner, tid eller mulighet til samarbeid mellom lærere og spesialpedagoger. På bakgrunn av dette utledes følgende problemstilling for studien: Hva forklarer spesialpedagogers opplevelser av trivsel $i$ arbeidet, og hva er belastningene?

Ved å vektlegge begrepet «trivsel» var det et mål at studien skulle ta utgangspunkt i positiv psykologi (Luthans, 2002), der oppmerksomheten rettes mot forhold som kan forklare at spesialpedagogene har positive opplevelser i arbeidet, for å på den måten også å kunne si noe om belastningene.

\section{Metode}

Det kvalitative forskningsintervjuet var et naturlig valg av metode for denne studien, da det var spesialpedagogenes egne erfaringer og subjektive perspektiver som sto i fokus. Utvalget besto av 11 spesialpedagoger som alle jobbet i norsk offentlig grunnskole. Informantene ble valgt strategisk ut fra egenskaper og kvalifikasjoner som var relevant for problemstillingen (Miles \& Huberman, 1994). De skulle ha minimum ett års utdanning i spesialpedagogikk og ha praktisert som spesialpedagog i minimum fem år. I tillegg skulle de ha ansvar for elever med enkeltvedtak om spesialundervisning i sin nåværende stilling. For å sikre en viss variasjon i utvalget ble det rekruttert spesialpedagoger fra to store bykommuner i Norge. De jobbet ved barneskoler (1.-7. trinn), ungdomsskoler (8.-10. trinn), eller barne- og ungdomsskoler (1.-10. trinn). Noen av skolene var små, andre middels, og noen store. Det endelige utvalget besto av kvinnelige spesialpedagoger med forholdsvis høy utdanning og lang erfaring. 


\section{Marit Uthus}

En antagelse inn i studien var at spesialpedagogene kunne oppleve belastninger i arbeidet. Dette var noe jeg som forsker måtte ta stilling til: Hvordan fange opp en eventuell kompleks virkelighet, slik den fremsto for spesialpedagogene? Hvor lett eller hvor vanskelig ville det være for spesialpedagogene å svare på spørsmål om det som kunne være uklart eller utfordrende? På bakgrunn av slike spørsmål kom jeg frem til at det var hensiktsmessig å utarbeide åpne intervjuspørsmål, der spesialpedagogene fikk fortelle fritt om arbeidet sitt, i tråd med det Tjora (2013) beskriver som en induktiv tilnærming til studiens empiri. Intervjuene ble dermed innledet med at informantene ble bedt om å dele sine umiddelbare tanker om arbeidet. Videre ble de stilt spørsmål av typen «Kan du beskrive gledene/forventningene/utfordringene du erfarer i arbeidet ditt for meg?». Innenfor de ulike temaene ble de stilt ulike oppfølgingsspørsmål, slik som «Kan du si noe mer om det?», "Hvorfor er det slik tror du?» Hvert intervju varte ca. 90 minutter. Før intervjuene startet ble alle orientert om at intervjuet var frivillig, og at de kunne trekke seg når som helst. Intervjuene ble tatt opp på lydbånd og transkribert.

I tråd med en induktivt orientert intervjuguide ble også analysene innledet nær empirien: Etter hvert intervju og under transkriberingen ble det skrevet spontane refleksjonsnotater med vekt på det unike i spesialpedagogenes fortellinger. Hva var den enkelte opptatt av i sitt arbeid, og hva hadde de til felles? Deretter ble 600 sider transkribert tekst lest. Målet var nå å redusere dette enorme datamaterialet til noen få tema, med underliggende kategorier og koder (Miles \& Huberman, 1994). Uttalelser som omhandlet deres positive erfaringer i arbeidet ble kodet og tematiske mønstre ble utforsket, for så at det samme ble gjort med tanke på uttalelser som beskrev utfordringer i arbeidet. I utgangspunktet var det fristende å enkelt forklare utfordringene i lys av ytre forhold, slik som at spesialundervisningen hadde lav prioritet ved skolene, men etter hvert som analyseprosessen skred frem viste det seg at forhold som forklarte deres opplevelse av trivsel i arbeidet også ga mening til belastningene. På dette stadiet så jeg derfor behovet for å velge teorier som kunne gi ny forståelse eller mening til spesialpedagogenes erfaringer på et indre kognitivt og emosjonelt plan, heller enn på et mer ytre eller beskrivende plan, som for eksempel profesjonsteori (Abbott, 1988). Når teoriene så var valgt, ble også neste fase i analyseprosessen mer teori-nær. Kategoriene for trivsel og belastninger ble nå utforsket i lys av teoretiske perspektiver og annen forskning. Som forsker beveget jeg meg her frem og tilbake mellom datamaterialet, ideene for studien, teori og tidligere forskning. Det sentrale analyseverktøyet, eller «devices and techniques used by analysts to facilitate the coding process» (Strauss \& Corbin, 1998, s. 87), var den konstante dialogen med datamaterialet, de nye spørsmålene som ble stilt og jakten på stadig nye sammenhenger.

\section{Teoretisk tilnarming}

Det ble som nevnt valgt teori som kunne gi mening til spesialpedagogenes opplevelser av trivsel og belastninger «innover», på et kognitivt og emosjonelt plan. 


\section{Verdier og motivasjon}

Motivasjonsforskerne Wigfield og Eccles (1992) beskriver i sin «expectancy-value» teori at forventning om å mestre og verdier forsterker hverandre, og dermed at begge er gjensidig viktige for motivasjon. Wigfield og Eccles (2000) skiller mellom fire ulike verdier vi mennesker kan motiveres av: Hvis en aktivitet er så viktig for oss at den bekrefter den oppfatningen vi har av oss selv, har den ifølge teorien en personlig verdi for oss. Indre verdi har også stor betydning for oss å få realisert, og beskrives som den interessen vi har for en aktivitet og gleden vi kan oppleve når vi utfører aktiviteten. Både personlig verdi og indre verdi gir en motivasjon som springer innenfra. Motivasjonen har da ikke opphav i ytre, eller utenforliggende forhold. Hvis aktiviteten har betydning for å nå fremtidige mål har den en nytteverdi. De negative konsekvensene av aktiviteten beskrives som kostnad.

\section{Verdidissonans}

Rosenberg (1977) betrakter et sosialt miljø som en kommunikasjonskontekst i den forstand at vi som deltakere i et sosialt system stadig mottar åpne eller skjulte signaler om hvilke verdier som verdsettes. Hvis vi oppfatter at egne verdier vurderes negativt i miljøet vil vi i lys av Rosenbergs (1977) teori føle oss annerledes, som at vi ikke hører til og at det er noe feil med oss. Når det å skille seg ut vekker en følelse av ubehag befinner vi oss i et dissonant miljø. Rosenbergs (1979) teori beskriver videre at hvis verdien vi har med oss inn i miljøet er dypt forankret i oss, vil ubehaget, og også selvvurderingene knyttet til det å skille seg ut, være desto sterkere negativt betont. I en slik situasjon vil vi ha behov for å beskytte vår selvoppfatning, for eksempel ved å gi opp våre verdier eller å forlate miljøet.

\section{Rolleteori}

Mertons (1957) rolleteori beskriver at vi befinner oss i ulike sosiale systemer, der rollen vi har må forstås ut fra de forventningene som rettes mot oss. Når det er ulike personer i slike systemer, som står i hver sine rollesett, oppstår det en kompleksitet der de ulike personene retter ulike forventinger til den enkelte. Det er med andre ord den enkeltes rollesett som avgjør hvilke forventninger vedkommende har rettet mot seg, og som dermed også kan forklare at vedkommende står ovenfor forskjellige, og også motsetningsfylte forventninger. Merton (ibid.) beskriver at konfliktfylte rollesett er lettere å leve med jo lenger avstand det er til den som representerer forventningene i rollesettet. Teorien sier videre at det finnes en optimal sone av kontroll, der gitte standarder for praksis balanseres med autonomi for personen som besitter en rolle.

\section{Sentrale forskningsfunn}

\section{Opplevelser av trivsel i arbeidet}

Spesialpedagogene som ga sine stemmer til denne studien formidlet at de var verdibaserte i sin yrkesutøvelse, både i form av verdier som var viktige for dem forut for 
yrkesvalget, men også verdier de vektla i arbeidet på det tidspunktet intervjuene fant sted:

Jeg har prøvd å tenke på hva det er som gir meg mest, og det er at jeg kan hjelpe elever som har vansker. Feg har bestandig vert opptatt av det, siden jeg gikk på barneskolen sjøl; å hjelpe de som ikke fär til ting, og som ikke er like flink. Feg føler at jeg kanskje forventer mer enn jeg klarer, fordi jeg har lyst til at alt skal vare perfekt, eller, ja, jeg vil det beste for elevene!

Det er for det forste den kontakten jeg har med elevene, jeg er jo enormt glad $i$ dem. Altså, jeg ser jo det, jeg gir dem en trygghet. Feg er viktig for dem. Og de små skrittene de tar, det at de opplever å fà ting til, og det å se de oppleve glede ved à mestre.

Feg tror at vi som samfunn vinner veldig mye på inkludering, ja det å vcere sammen $i$ et fellesskap, og det at det er rettferdig ikke à behandles likt, at man ser at man har et mangfold.

At valget av yrket var et verdivalg viste seg på den måten at spesialpedagogene så på seg selv som en person som gjorde en forskjell for mennesker som strever. De ønsket å bidra til det beste for elever med særskilte opplæringsbehov i skolen. Som flere av dem formidlet, var de selv klar over at deres egne ambisjoner overgikk det som var mulig å få til for elevene. Når det kom til den verdien selve yrkesutøvelsen hadde for dem, viste de til gleden som fulgte med å være i nære relasjoner til disse elevene. De beskrev den positive emosjonelle kontakten med elevene, og at de kunne merke hvor viktig denne kontakten var for elevenes trygghet, trivsel og læring i skolen. Samtlige formidlet at yrket hadde stor verdi for dem på den måten at det bidro til at elevene fikk lære, utvikle seg og ta del i inkluderende fellesskap, til tross for utfordringer og vansker. De reflekterte også over inkluderingens berikende potensial for medelever og lærere, og de så det som sin oppgave å bidra til økt toleranse og respekt for ulikhet; både ved skolene der de jobbet, og i samfunnet generelt. Til sammen viste det seg at verdidimensjonen ga spesialpedagogene viktige opplevelser av mening og glede $\mathrm{i}$ arbeidshverdagen.

Videre formidlet spesialpedagogene at de representerte ulik spisskompetanse innenfor feltet, som for eksempel språk og kommunikasjon, lese- og skrivevansker og sosio-emosjonelle vansker. De formidlet at denne kompetansen var avgjørende for at de skulle mestre arbeidet. Dessuten var de trygge på at det var bruk for den i en skole ment å romme elevmangfold. Denne vissheten om at de bidro med en kompetanse som var viktig, viste seg å danne grunnlaget for deres yrkesstolthet:

fa, jeg vil absolutt si at jeg er en stolt spesialpedagog! feg ser helt klart behovet for den spesialpedagogiske kompetansen og spesialpedagogen! Til tross for at kommunen har tenkt «tilpasset opplering» for alle elever. Det idealet er ikke så lett å få til altså! Med de rammene som finnes blir det så «idealisert»: Det er noen unger som, uansett hvor mye tilpasset opplaring og spesialundervisning de fär innenfor den ordincere undervisningen, så opplever de ikke mestring. 
Samtlige av spesialpedagogene viste til at kommunen de jobbet i la klare føringer for at skolene skulle drive tilpasset opplæring innenfor den ordinære undervisningen, og redusere omfanget spesialundervisning. De beskrev at signalene de mottok, både fra ansatte i kommunens utdanningsetat og fra rektorene, var at hvis den ordinære undervisningen nådde et optimalt nivå for tilpasning, så ville den spesialpedagogiske kompetansen bli overflødig. For spesialpedagogene var det lett å tolke dette som at de selv også ble vurdert som overflødige, som at det ikke var bruk for dem i skolen. Samtidig var det opplagt for dem at disse føringene var ideologisk basert. I realiteten så de at lærerne sto overfor store utfordringer med å skulle håndtere elevmangfold i skolens ordinære undervisning. Dessuten, etter mange års yrkeserfaring, var de overbevist om at det alltid vil være elever der som trenger deres spesialpedagogiske kompetanse for å kunne ta del på like vilkår. Derfor hadde spesialpedagogene selv en opplevelse av å være betydningsfulle.

Det var den spesialpedagogiske kompetansen de viste til når de skulle forklare sin motivasjon for å fortsette i yrket:

Det er liksom spesialpedagogikk som er mitt FAG. Og jeg fär jo brukt utredningskompetansen $i$ skolen også. Feg synes jo det er veldig spennende à utrede da. Og likedan lesegruppene og rettskrivingskursene synes jeg er kjempeartig. Og også oppfølginga av eleven med Downs syndrom!

Feg har lyst til å fortsette med dette! Etter alle disse årene så blir arbeidet lettere og lettere; à kartlegge, og finne metoder som fungerer, og det à stadig stå ovenfor nye utfordringer og sette seg inn $i$ nye elever. Og det er fordi jeg brenner sånn for dette. Og jeg ser jo at jeg får ting til, hele veien.

Spesialpedagogene beskrev at den spesialpedagogiske kompetansen de var i besittelse stadig utviklet seg gjennom mange års yrkeserfaring. Som en av dem uttalte, så visste hun med seg selv at hun hadde tilstrekkelig kompetanse til å mestre arbeidsoppgavene selv når elevgrunnlaget eller andre ytre forhold ble endret.

Videre viste analysene at spesialpedagogenes daglige erfaringer sammen med elevene, relasjonene som utviklet seg og den unike innsikten de hadde om den enkelte elev var viktig for dem i arbeidet:

feg får et veldig godt forhold til disse elevene, for jeg blir jo så ncer de. Og jeg har mye forstålse for den situasjonen de er $i$, som gjør at jeg kanskje beskytter de fra andre larere som ser på dem som umulige. Fordi jeg kommer så ner de, så klarer jeg å se BAK det umulige; GRUNNEN til at de er slik. Hvis jeg ser at de ikke har det bra når de er inne $i$ klassen, så prøver jeg å inkludere de mer.

Spesialpedagogene beskrev at den nære kontakten med elevene ga dem en unik innsikt i elevene, deres behov, læringsutfordringer og -muligheter, elevenes opplæringstilbud, deres opplevelser av dette, de ytre fysiske rammene og elevenes sosiale relasjoner både til lærere og medelever. I situasjoner der spesialpedagogene opplevde at de var de eneste som så hva disse elevene trengte, eller hvilke ressurser og muligheter de hadde, ble det også deres ansvar å fronte dette ovenfor lærere og rektor. 


\section{Marit Uthus}

Videre viste det seg at dimensjonen av nærhet fikk betydning for spesialpedagogene i samarbeidet med ansatte i det spesialpedagogiske støttesystemet:

De elevene med autisme som jeg har, de fire, de er jo like forskjellige som natt og dag! Vel har de noen likheter eller noen scrtrekk, men det har vi jo alle. Du kan jo finne noe som er likt uansett om de har ADHD eller er autister. Og man kan finne like mye forskjeller! Blir du ikke kjent med det enkelte mennesket så kommer du jo ingen vei. Da er det ingen nytte $i$ planer og skjemaer.

Mens spesialpedagogene kunne erfare at ansatte i støttesystemet baserte sitt arbeid på en form for "diagnosekunnskap», var de selv opptatt av å utvide denne kunnskapen med den innsikten de var i besittelse av; nemlig i mennesket bak diagnosen. Der de befant seg nær elevene i skolehverdagen opparbeidet de seg en unik helhetlig kunnskap om enkeltelever, hva deres betingelser for læring og utvikling var, og også hva betingelsene for deltakelse i fellesskapene var. Særlig interessant viste det seg også at det ikke var elevenes utfordringer spesialpedagogene fokuserte mest på, men tvert imot deres ressurser og muligheter.

Gjennom analysene ble det klart at spesialpedagogenes posisjon nær elever med særskilte behov understøttet både deres verdibaserte ønsker om å praktisere til det beste for elevene, og deres spesialpedagogiske kompetanse. Som en av dem forklarte hadde den spesialpedagogiske kompetansen blitt hennes yrkesidentitet, slik at hun ikke lenger bare kunne «legge den fra seg»: Spesialpedagogikk var et fag hun kunne, nærmest som et «håndverk». Slik ble det klart at spesialpedagogene ikke bare representerte en yrkesstolthet, de representerte like mye en yrkesbevissthet.

\section{Belastningene}

Spesialpedagogenes klare verdiforankring, deres helhetlige spesialpedagogiske kompetanse og nærhet til elevene i skolehverdagen, var en kilde til trivsel i arbeidet. Samtidig viste det seg at de opplevde til dels store belastninger.

Spesialpedagogene opplevde at idealet om en inkluderende skole forble mest fine ord i skolens verdiplattform. Realiteten der de befant seg, med ansvar for skolens spesialundervisning, så annerledes ut.

Det stilles krav til oss $i$ norsk skole om at vi skal øke kunnskapsnivået blant elevene! Noen lerere har tatt dette veldig inn over seg. Og de er kjempedyktige på å lage massevis av planer og de er veldig opptatt av å undervise... Og hvis planene og undervisningen blir forstyrret av elever med scerskilte behov, så vet jeg ikke om de ønsker å ta ansvar for dem.

Det viste seg at spesialpedagogene opplevde at læringstrykket var stort ved skolene der de jobbet. Slik de oppfattet det var både rektorer og lærere sterkt forpliktet på kunnskapstestene. De fortalte at rektors valg og prioriteringer i denne situasjonen ikke gikk i favør elevene med særskilte behov og spesialundervisningen.

De beskrev at det høye arbeidspresset på lærerne førte til at de hadde mindre kapasitet til å samarbeide med dem om elevene med særskilte behov og spesialundervisningen: 
Lerere har mer enn nok med resten av elevene; masse fremmedspråklige elever, og andre elever som heller ikke fär det de har rett på. Larerne sier, "bare ta ansvar for eleven med sarskilte behov du, det er ditt ansvar.

Feg skjønner ikke at rektor kan si at elevene har fätt nok ressurser. Det er jo ressursmangel! Og så blir budskapet hans liksom; "Det er ikke optimalt, men det er BRA NOK》. Feg fär hele tiden høre; "Du må ikke stille så store krav til deg sjøl». Men jeg synes ikke det elevene fär er bra nok.

Gapet mellom spesialpedagogenes verdier og de verdiene som de oppfattet ble signalisert i kollegafellesskapet fremsto dermed som stort. Realiteten for dem var at de representerte en isolert og mindreverdig praksis ved skolene der de jobbet.

En av spesialpedagogene fortalte at hun hadde ansvar for fire elever som alle hadde hver sine vedtak, med rett til hver sine individuelt tildelte 15 timer spesialundervisning i uka. I realiteten måtte elevene dele 15 timer i et segregert tiltak, klart i strid med deres individuelle vedtak og juridiske rettigheter. Elevene var plassert i skolens øverste etasje, oppe på et uinnredet lagerrom:

For å si det sånn, man må nesten se det... Eleven som er født for tidlig, har store problemer med å gå og å se. Og så er det en elev som har angst, vi kan ikke ta heisen for han har sånn angst. Og så er det hun med et syndrom, som plutselig må på do, så da må jeg ta med meg de tre andre elevene. Og så klarer vi ikke å gå fort nok på do, fordi han som er født for tidlig ikke klarer å gå fort nok. Og vi kan jo ikke ta heisen, fordi han med angst ikke klarer det. Så da ender det jo med at hun som må på do gjør $i$ buksen... Og da må jeg plassere de andre tilbake $i$ klassen... altså det er mye løping rundt på bygget. Det blir... mye oppbevaring. Alle de fire elevene trenger hjelp HELE tiden. Feg ser jo hva de kunne ha fätt til, hvis de hadde fätt det de hadde rett på.

Spesialpedagogen som uttalte seg i dette utsagnet fikk ikke praktisert en opplæring som elevene hadde rett på etter opplæringsloven. All den tid det var hun som sto med det daglige ansvaret for elevenes spesialundervisning, opplevde hun dette som en stor belastning. Elevene fikk ikke utnyttet sine potensial for læring, vekst og utvikling. Deres juridiske rettigheter ble heller ikke etterfulgt.

I posisjonen nærmest elevene med særskilte behov opplevde spesialpedagogene en sterk forpliktelse på å si fra om det som ikke ble bra nok for elevene:

Feg har oppfordret foreldrene til å følge med på at elevens rettigheter blir overholdt, men de har jo kanskje ikke kapasitet til à ta fighten. Og rektor har gitt meg beskjed om at jeg ikke har lov til à si til foreldrene at oppleringstilbudet til eleven ikke er godt nok.

Spesialpedagogen fortalte her om foreldre som ikke hadde kapasitet eller ressurser nok til å passe på sitt barns rettigheter, og at dette ikke ga henne noe valg annet enn å selv måtte innta rollen som elevens "talerør» eller "advokat». På den ene siden kunne en slik rolle redusere de belastningene som hun opplevde; hun gjorde tross alt det som sto i hennes makt å gjøre. Men på den andre siden fulgte det opplagt en ny form for belastning for henne med å innta en slik rolle, all den tid hun ikke vant frem: 
Feg klarer ikke dette $i$ lengden. Feg begynner à bli sliten. Feg er jo enig $i$ det som står på papiret fra fagpersoner; "Hun skulle hatt sånn». Og ja, herregud, hun skulle hatt sånn! feg synes det er helt forferdelig! Feg har slitt ganske mye, gått $i$ kjelleren, dratt det mye med meg. feg føler jo ALDRI at jeg strekker til. feg fär aldri gjort tingene ordentlig; fär aldri jobbet ferdig med noe, fär aldri gitt elevene det de trenger. Feg føler egentlig at jeg bare slokker brann. Feg lever med konstant dårlig samvittighet. Feg tar med meg bekymringene hjem. Så til slutt måtte jeg gå til fastlegen og be om sykemelding.

Flertallet av spesialpedagogene som deltok i denne studien beskrev at de investerte mer i arbeidet sitt enn de hadde kapasitet til, og at de derfor også hadde en viss opplevelse av å lykkes, rammebetingelsene tatt i betraktning. Like fullt var det stor usikkerhet for flere av dem knyttet til hvor lenge de ville klare å holde ut i arbeidet. I denne situasjonen fremsto det ekstra sårbart å oppleve å stå alene i arbeidet:

feg merker jo at jeg ikke hører til noe sted. Larerne jobber $i$ team. Det gjør ikke jeg. Feg jobber alene. Så det der er litt sånn en tung bit.

Mangel på støtte i kollegafellesskapet ble ekstra utfordrende når de i tillegg erfarte at rollen som spesialpedagog ikke egentlig var verdsatt, verken på skolen de jobber, i kommunen, eller i skolesystemet generelt:

Det å vcere spesialpedagog $i$ skolen $i$ denne kommunen, det er jo litt sånn uglesett. Det er jo liksom «tilpasset opplaring» som gjelder. Rollen som spesialpedagog har blitt utvannet. Altså, du kan si det sånn, at som spesialpedagog $i$ skolesystemet, så er man litt sånn på siden. Det à vaere kontaktlarer og ha klasse, det er litt mer verdsatt på en måte. Som spesialpedagog har du alltid med disse svake og disse scerskilte elevene å gjøre, og du blir på en måte assosiert med dem.

Mens spesialpedagogene selv erfarte at det var bruk for deres kompetanse og at den var avgjørende for at elevene skulle lære og utvikle seg, ta del og mestre i skolefellesskapet, uteble en bekreftelse på dette fra andre ansatte ved skolen. Signalene de mottok var at lærerkollegene satte pris på å få avlastning for de av elevene som strevde mest. Når reell verdsettelse uteble, opplevdes dette som en belastning for dem:

feg synes det er respektløst ovenfor elevene og jeg synes det er respektløst ovenfor meg som fagperson... Feg har bestemt meg for ikke å fortsette å jobbe som spesialpedagog. Feg har sagt at jeg enten starter opp med klasse til neste år, eller så må jeg finne meg en ny jobb.

For spesialpedagogene som sto nærmest elevene i skolehverdagen ble det en nær forbindelse mellom det som var respektløst ovenfor eleven, og det som var respektløst ovenfor dem selv som yrkesutøvere i en skole for alle elever. For flere av dem virket det som et spørsmål om tid før de ga opp arbeidet sitt.

\section{Drøfting}

Funn i denne studien viser at spesialpedagogene har opplevelser av trivsel i arbeidet sitt i den norske offentlige grunnskolen. På grunnlag av en sterk verdibasert 
motivasjon, spesialpedagogisk kompetanse, samt en nærhet til elevene, med dertil positive relasjoner og verdifull innsikt om elevene, blir det klart for dem at de har det som skal til for å bidra til læring og utvikling for elevene i inkluderende fellesskap. De har da også et sterkt ønske om å lykkes med dette. Samtidig blir det klart at de ikke har gode vilkår i så måte, noe som kan forstås i lys av utdanningspolitiske taktskifter (Imsen, Blossing \& Moos, 2017). Ifølge spesialpedagogene har målet om inkludering lav prioritet ved skolene der de jobber, noe som må forstås i lys av at både rektorer (Møller, 2019) og lærere (Mausethagen, 2013) står ovenfor forventninger om å heve elevenes skolefaglige prestasjoner. Når flere effektivitets- og resultatbaserte målsettinger preger skolehverdagen er det ikke lenger elevene med behov for spesialundervisning som prioriteres.

Nokså overraskende viser det seg at utfordringene spesialpedagogene erfarer ikke ensidig lar seg forklare i lys av ideologiske taktskifter og «hardere» tider. Nedprioriteringen av skolens spesialundervisning må også forstås i lys av de ensidig systemorienterte føringene, slik disse ble presentert innledningsvis i denne artikkelen, der spesialundervisningen (og derigjennom spesialpedagogen) har blitt oppfattet å stå i veien for inkludering (Bachmann \& Haug, 2006; Kunnskapsdepartementet, 2010-11; Kunnskapsdepartementet 2012-2013). For spesialpedagogene fremstår situasjonen som et stort paradoks på den måten at argumentet om mindre spesialundervisning ment å fremme inkludering, blir brukt av skoleeier og rektor til å legitimere det stikk motsatte, som er en segregert, ulovlig og til dels uverdig spesialpedagogisk praksis. I denne situasjonen settes spesialpedagogenes verdier, deres spesialpedagogiske kompetanse og deres nærhetsbaserte relasjoner og innsikt i elevenes beste, på prøve. Slik trer det frem at det er en nær kobling mellom spesialpedagogenes opplevelser av trivsel og belastninger i arbeidet. Dette vil nå utdypes i lys av valgte teori. I tråd med studiens induktive utgangspunkt vil også noe ny forskning refereres, for å gi en utdypende forståelse - og for validering av studiens funn (Kleven, 2008).

\section{Verdier}

I lys av Wigfield og Eccles (1992) teori om verdier, blir det klart at våre spesialpedagoger har en indre, verdibasert motivasjon for arbeidet: De har ansvar for en gruppe elever som strever mer enn andre elever i skolen, som lettere faller utenfor, og som trenger noe annet og noe mer for å kunne ta del på lik linje. Spesialpedagogene er villige til å strekke seg langt for å yte det beste for disse elevene, og i kraft av sin posisjon nær elevene i skolehverdagen er det elevenes beste i helhetlige og inkluderende perspektiver de orienterer sin praksis mot. Slike inkluderende holdninger hos spesialpedagoger bekreftes også i annen forskning (Groven, 2007; Göranson et al., 2015; Göranson et al., 2017; Lindqvist et al., 2011; Mjøs, 2017; Uthus, 2014).

For å forstå hva som er unikt når det kommer til spesialpedagogenes verdier kan det være nyttig gå til forskningen på sykepleiere, som i likhet med spesialpedagogene har ansvar for mennesker som strever. For sykepleiere beskrives den essensielle verdien ved yrkesutøvelsen å være knyttet til å kunne yte omsorg, eller «caring» for mennesker 


\section{Marit Uthus}

som trenger hjelp, noe som innebærer at en setter seg selv til side (Watson, 1985). Denne formen for motivasjon beskrives som altruistisk, eller pro-sosial motivasjon (Dill, Erickson \& Diefendorff, 2016); en form for motivasjon som sammenlignes med en personlig egenskap hos de som velger sykepleieryrket, som at de svært høye ambisjonene om å hjelpe andre er deres «identitet». Dette kan altså gjenkjennes hos våre spesialpedagoger. Som den ene av dem forteller, har hun vært opptatt av å hjelpe de som strever helt siden hun var liten, og ambisjonen hennes er intet mindre enn det perfekte for dem.

På dette grunnlaget trer det frem at spesialpedagoger ikke nødvendigvis bare har en indre verdibasert motivasjon for å velge yrke. De kan også representere det som i lys av Wigfield og Eccles (1992) sin teori kan beskrives som personlig verdibasert motivasjon. Dette innebærer i så fall at yrket vil ha stor betydning for dem på den måten at det bekrefter den oppfatningen de har av seg selv; som at de nærmest er sitt yrke, eller sin «yrkesidentitet». Denne formen for motivasjon kan, som vi har sett for våre spesialpedagoger, være positiv på den måten at spesialpedagogene strekker seg optimalt for å lykkes i arbeidet. Samtidig erfarer de til dels store belastninger med å identifisere seg for tett opp til arbeidet med elevene med særskilte behov. Når de «er» sitt yrke, blir det vanskeligere for dem å opprettholde en sunn distanse til det stresset som oppstår når de ikke lever opp til egne ambisjoner om det beste for elevene.

\section{Spesialpedagogisk kompetanse}

Videre viser analysene i denne studien at spesialpedagogene er stolte av den spesialpedagogiske kompetansen som de besitter. De erfarer at det er bruk for deres kompetanse, både fordi de ser at læreres allmennpedagogiske kompetanse ikke er tilstrekkelig for å ivareta hele spredningen i elevenes læreforutsetninger og behov, men også som følge av at de erfarer at den ordinære undervisningen praktiseres mer ensrettet enn før.

Problemet for spesialpedagogene er imidlertid at de ikke har gode rammebetingelser for å ta i bruk sin spesialpedagogiske kompetanse. Slik den ene spesialpedagogen forteller må elever med svært ulike behov og forutsetninger dele sine individuelt tildelte timer til spesialundervisning, og realiteten for henne er at hun praktiserer oppbevaring mer enn opplæring eller inkludering. Andre kilder underbygger dette bildet, både hva angår tendensen til segregert spesialundervisning (Utdanningsspeilet, 2018a) og nedprioritering og marginalisering av elever med særskilte behov i skolen (Barneombudet, 2017; Wendelborg, 2014; 2017). Sett fra spesialpedagogenes side oppleves det som at deres kompetanse og arbeidsoppgaver har minst «verdi» i kollegafellesskapet. Den verdsettelsen som de da får for å ta ansvar for det ved skolens virksomhet som andre helst vil unnslippe, oppleves for dem som en skinn-verdsettelse; en form for verdsettelse som går på verdigheten løs.

\section{Nærhet til elever med særskilte behov}

Et annet sentralt funn i denne studien er at spesialpedagogene erfarer at deres posisjon nær elevene med særskilte behov har stor betydning for at de skal lykkes i arbeidet. 
Med denne nærheten følger bl.a. at de kan etablere gode relasjoner til elevene, noe som har betydning for elevenes trivsel, utvikling og læring. Tilsynelatende kunne en slik nærhet og erfart sannhet om relasjonens betydning ha ført til at spesialpedagogene ønsket å praktisere individrettet, heller enn systemrettet, slik føringene stiller krav om (Kunnskapsdepartementet, 2010-11; Kunnskapsdepartementet, 2012-2013). Dette ville i så fall samsvare med en tilbakevendende kritikk mot spesialpedagoger, som at de ønsker å praktisere en tradisjonell individ- og vanskeorientert spesialundervisning (Nordahl, 2018). I realiteten skjer altså det motsatte: Med nærheten til elevene følger nemlig at spesialpedagogene opparbeider seg en unik innsikt i hva elevene trenger i et helhetlig perspektiv, det vil si både på et individuelt plan og hva angår deltakelse i læringsfellesskapene. Deres motivasjon er derfor også å praktisere systemrettet, på den måten at de vil bidra med sin unike innsikt om elevens ressurser og muligheter, slik at andre, både kolleger og medelever, oppnår samme innsikt, og dermed kan endre sine holdninger til å bli mer positivt innstilt ovenfor eleven. En slik systemrettet tilnærming til egen profesjonsutøvelse er godt bekreftet å gjelde for spesialpedagoger også i andre studier (Groven, 2007; Göransson et al., 2015, Göransson et al., 2017; Lindqvist et al., 2011; Mjøs, 2007; Uthus, 2014). Når så Nordahls ekspertutvalg (2018) viser til at spesialundervisningen er individ- og vanskeorientert, som at feilen ligger hos spesialpedagogene, kan altså dette være en svært uheldig forenkling av det hele bildet. Sett i lys av funnene i denne studien kan det derfor være hensiktsmessig å lytte mere til spesialpedagogene i fremtidig forskning: Hva trenger de for å kunne praktisere god og inkluderende spesialundervisning?

\section{Trivsel og belastninger som ett og samme fenomen, bare med motsatt fortegn}

Funnene i denne studien har vist at dimensjonen av nærhet til elevene utgjør en kilde til mening og glede for spesialpedagogene så lenge de opplever å innfri sine ambisjoner om det beste for elevene. Men så fort de opplever at situasjonen er utilfredsstillende for elevene, og de ikke innfrir sine egne verdibaserte ambisjoner, blir belastningene som følger med nærhet til elevene desto større. I denne situasjonen må vi huske på at både lærere og rektorer har større avstand til elevene med særskilte behov enn det spesialpedagogene har. Det betyr, i lys av Mertons (1957) rolleteori, at de også vil være mindre forpliktet til disse elevene, og dermed også at de vil oppleve mindre belastninger knyttet til tendensen til nedprioritering og marginalisering av denne elevgruppen. Slik De Boer og kolleger (2011) finner, bekreftes dette i form at læreres nøytrale eller negative holdninger til inkludering. Videre beskriver Wigfield og Eccles (1992) i sin teori at det er graden av belastninger, eller kostnaden, som avgjør hvilke verdier de ulike medlemmene i rollesettet bevarer eller forkaster. Derfor, siden opplevelsen av kostnad knyttet til å prioritere på tvers av det som blir best for elevene vil være minst for rektorer (som ikke automatisk befinner seg fysisk nær elevene i skolehverdagen), vil det altså være lettest for dem å forplikte seg på mere nytte- og effektivitetsorienterte verdier, slik det legges opp til fra myndighetenes side. Spesialpedagogenes belastninger i arbeidet handler således ikke enkelt om å stå alene 


\section{Marit Uthus}

om sine bekymringer for elevene med særskilte behov: Det handler om en tiltakende følelse av at deres verdier blir satt på prøve i kollegafellesskapet.

Slik Rosenbergs $(1977,1979)$ teori om kontekstuell dissonans tilsier, vil opplevelsen av at egne verdier settes på prøve i kollegafelleskapet ha negative konsekvenser for spesialpedagogene på den måten at de vil kunne oppleve at de ikke blir akseptert eller verdsatt. Som allerede vist til, er opplevelse av lavt samsvar mellom skolens rådende verdier og egne verdier studert for lærere, med den konklusjonen at dette kan medføre negative emosjoner og stress (Skaalvik \& Skaalvik, 2017). Selv om belastninger som følge av mangel på verdisamsvar ikke tidligere er dokumentert for spesialpedagoger, samsvarer det likevel med annen forskning. Denne viser til at spesialpedagogene opplever å stå alene med sine ambisjoner for elever med særskilte behov i kollegafelleskapet, at det er uklart hva deres rolle og praksis skal være, samt at de har lav status sammenlignet med andre yrkesgrupper i skolen (Göranson et al., 2015, Lindqvist et al., 2011; Magnússon \& Göransson, 2018; Uthus, 2014).

Når spesialpedagogenes verdier settes på prøve, tar de på seg ansvaret for å undersøke og formidle elevenes juridiske rettigheter, både til rektorer, lærere og foreldre. Dette kan forstås som et forsøk fra deres side på å redusere det indre emosjonelle ubehaget som Rosenberg $(1977,1979)$ beskriver gjelder for kontekstuell dissonans. Problemet er at de ikke blir hørt. Tvert imot nektes de å formidle til foreldre at elevenes rettigheter ikke oppfylles. Dermed, stikk i strid med hva de kanskje hadde sett for seg, eskalerer deres indre opplevelse av dissonans. Faktisk kan det se ut som at det er denne «advokat-rollen» som utgiør den berømte dråpen for spesialpedagogene, som medfører at belastningen de opplever i arbeidet til slutt blir for stor. Spesialpedagogene som er deltakere i denne studien beskriver opplevelser av avmakt og symptomer på stress og utmattelse. Flere har vært sykemeldt over lengre tid og disse har tanker om å slutte i arbeidet som spesialpedagog, noe som i lys av Wigfield og Eccles sin teori (1992) om personlige verdier kan tolkes som at de er i ferd med å gi opp «seg selv». Fallet kunne i tilfelle ikke vært større. Arbeidet som spesialpedagog i norsk offentlig grunnskole kan på dette grunnlaget opplagt ha sine omkostninger.

\section{Studiens implikasjoner}

Forskningsfunnene i denne studien utleder et behov for mer innsikt når det kommer til de uheldige konsekvensene av målstyrte og flere harde styringsprinsipper for skolen, ikke bare for spesialpedagogene og deres yrkesutøvelse, men også for elever med særskilte behov og deres mulighet til å ta del i fellesskapet og ha utbytte av opplæringen, slik inkluderingsideologien vektlegger (Ainscow \& César, 2006). Videre må ny forskningsbasert kunnskap om slike uheldige konsekvenser få betydning i utdanningspolitiske beslutningsorgan. Hvis det er slik at vi fortsatt har mål om å realisere en inkluderende skole, og en "målstyrt» utdanningspolitikk viser seg å utgiøre en inkluderingshemmende faktor, kan en mindre målstyrt utdanningspolitikk kanskje ha noe for seg. 
Selv om ideologiske taktskifter i skolen ser ut til å utfordre spesialpedagogene i arbeidet, må ikke dette bli stående som den eneste forklaringen på utilfredsstillende vilkår for deres yrkesutøvelse. Vilkårene må også ses i lys av forvaltningen av spesialpedagogikken som fag og praksis over de siste tiårene, der en har tenkt at spesialundervisningen står i veien for det overordnende målet om en inkluderende skole. Med denne studien utfordres denne oppfatningen. Spesialundervisning, slik våre spesialpedagoger ønsker å praktisere den, har mål om å ivareta elevenes individuelle behov og forutsetninger, og de ser dette som en nødvendig forutsetning for å kunne bidra til at elevene opplever å meste og ta del i leringsfellesskapene.

På dette grunnlaget utledes et argument om at inkluderingsbegrepet må utvides til å handle om mer enn hvor elever er plassert, innenfor eller utenfor ordinær opplæring. En skole kan sies å være inkluderende først når hver enkelt elev får ivaretatt sine behov og opplever å høre til, ta del og mestre i et læringsfellesskap (Uthus, 2017a; 2017b). Når vi forstår inkludering slik, som et subjektivt og opplevelsesbasert begrep, trer det også tydeligere frem at inkludering ikke er noe verken rektorer, lærere eller spesialpedagoger kan realisere alene. Inkludering omhandler alle skolens ansatte og alle dens elever, og både demokratiske, faglige, sosiale og emosjonelle prosesser må holdes under oppsyn og jobbes med i et samlet personale.

Spesialpedagogene som er intervjuet i denne studien formidler et sterkt verdibasert ønske om å utgjøre en ressurs i skolen når det kommer til ambisjonen om en inkluderende skole. Dette tilsier at det er hensiktsmessig å etablere bedre rammer for spesialpedagogenes arbeid, der de gis mulighet til å ta selvstendige beslutninger til det beste for elever som mottar spesialundervisning. Slik Merton (1957) vektlegger i sin rolleteori, finnes det en optimal sone av kontroll, der gitte standarder for praksis balanseres med autonomi for den praksisutøvende.

Studien har noen begrensninger. 11 spesialpedagoger er dybdeintervjuet og funnene $\mathrm{i}$ denne studien er ikke representative for flere enn disse 11. Det foreligger svært begrenset forskning med samme fokus og design som denne. De sentrale funnene kan dermed fremstå som «unike». Likevel er det slik at funnene i denne studien understøttes av annen forskning, og slik styrker studiens ytre validitet (Kleven, 2008).

\section{Forfatteromtale}

Marit Uthus jobber som førsteamanuensis i spesialpedagogikk ved Institutt for lærerutdanning, NTNU. Hennes forskning har fokus på blant annet den inkluderende skolen, elever med særskilte behov og spesialpedagogenes arbeid. Hun er også opptatt av pedagogisk- psykologiske tema knyttet til skolens læringsmiljø, elevers selverd, motivasjon og selvbestemmelse (agency), og derigjennom folkehelse og livsmestring som tema for nye læreplaner som trer i kraft fra 2020.

\section{Referanser}

Abbott, A. (1988). The system of professions: An essay on the division of expert labor. Chicago: University of Chicago Press. 


\section{Marit Uthus}

Ainscow, M. \& César, M. (2006). Inclusive education ten years after Salamanca: Setting the agenda. European Fournal of Psychology of Education, 21(3), 231-238.

Arnesen, A. L. \& Lundahl, L. (2006). Still social and democratic? Inclusive education policies in the Nordic welfare states. Scandinavian journal of educational research, 50(3), 285-300.

Bachmann, K. \& Haug, P. (2006). Forskning om tilpasset opplering. Forskningsrapport nr. 62. Hentet fra https:// www.udir.no/globalassets/upload/forskning/5/tilpasset_opplaring.pdf

Barneombudet (2017). Uten mål og mening? Elever med spesialundervisning $i$ grunnskolen (Barneombudets fagrapport 2017). Hentet fra http://barneombudet.no/wp-content/uploads/2017/03/Bo_rapport_enkeltsider.pdf

Cameron, D. L. \& Lindqvist, G. (2014). School district administrators' perspectives on the professional activities and influence of special educators in Norway and Sweden. International fournal of Inclusive Education, 18(7), 669-685.

Cameron, D. L. \& Tveit, A. D. (2015). Considerations on the evolving role and practice of the special educator in Norway. I D. L. Cameron \& R. Thygesen (Red.), Transitions in the field of special education: Theoretical perspectives and implications for practice (s. 73-90). Münster: Waxmann Verlag.

Cameron, D. L., Tveit, A. D., Jortveit, M., Lindqvist, G., Göransson, K. \& Nilholm, C. (2018). A comparative study of special educator preparation in Norway and Sweden. British fournal of Special Education, 45(3), 256-276.

De Boer, A., Pijl, S. J. \& Minnaert, A. (2011). Regular primary schoolteachers' attitudes towards inclusive education: A review of the literature. International journal of inclusive education, 15(3), 331-353.

Dill, J., Erickson, R. J. \& Diefendorff, J. M. (2016). Motivation in caring labor: Implications for the well-being and employment outcomes of nurses. Social Science \& Medicine, 167, 99-106.

Gillespie, A. (2016). Lcerersamarbeid om tilpasset opplcering $i$ matematikk. En kvalitativ intervjuundersøkelse av faglcereres og spesiallcereres opplevelse av samarbeid om elever med spesialundervisning $i$ matematikk på 9. trinn (Doktoravhandling). Universitetet i Oslo, Oslo.

Groven, B. (2007). Det doble blikk - spesialpedagogen i endringstider (Doktoravhandling). Norges teknisknaturvitenskapelige universitet, Trondheim.

Göransson, K., Lindqvist, G., Möllås, G., Almqvist, L. \& Nilholm, C. (2017). Ideas about occupational roles and inclusive practices among special needs educators and support teachers in Sweden. Educational review, 69(4), 490-505.

Göransson, K., Lindqvist, G. \& Nilholm, C. (2015). Voices of special educators in Sweden: a total-population study. Educational Research, 57(3), 287-304.

Imsen, G., Blossing, U. \& Moos, L. (2017). Reshaping the Nordic education model in an era of efficiency. Changes in the comprehensive school project in Denmark, Norway, and Sweden since the millennium. Scandinavian fournal of Educational Research, 61(5), 568-583.

Kleven, T. A. (2008). Validity and validation in qualitative and quantitative research. Nordisk pedagogik, 28(3), 219-233.

Kunnskapsdepartementet. (2010). Laring og fellesskap. Tidlig innsats og gode laringsmiljøer for barn, unge og voksne med scerlige behov. (Meld. St. 18 2010-11). Oslo: Kunnskapsdepartementet.

Kunnskapsdepartementet. (2012). På rett vei. Kvalitet og mangfold i fellesskolen. (Meld. St. 20 2012-13). Oslo: Kunnskapsdepartementet.

Lindqvist, G. (2013). SENCOs: vanguards or in vain? Fournal of Research in Special Educational Needs, 13(3), 198-207.

Lindqvist, G., Nilholm, C., Almqvist, L. \& Wetso, G. M. (2011). Different agendas? The views of different occupational groups on special needs education. European fournal of Special Needs Education, 26(2), $143-157$.

Luthans, F. (2002). The need for and meaning of positive organizational behavior. fournal of organizational behavior, 23(6), 695-706.

Magnússon, G. \& Göransson, K. (2018). Perimeters of, and challenges to, the jurisdiction of Swedish special educators: an exploration of free text responses. European fournal of Special Needs Education, 34(3), $257-271$.

Mausethagen, S. (2013). Accountable for what and to whom? Changing representations and new legitimation discourses among teachers under increased external control. Fournal of Educational Change, 14(4), 423-444.

Merton, R. K. (1957). The role-set: Problems in sociological theory. British fournal of Sociology, 8(2), 106-120.

Miles, M. B. \& Huberman, A. M. (1994). Qualitative data analysis: An expanded sourcebook. Thousand Oaks, CA: Sage Publications. 
Miller, J. \& Glassner, B. (1997). The 'Inside' and 'Outside': Finding Realities in Interviews. I D. Silverman (Red.), Qualitative Research: Theory, Method and Practice, (s. 99-112). London: Sage.

Mjøs, M. (2007). Spesialpedagogens rolle $i$ dagens skole: en studie av hvordan prinsippene om inkludering og tilpasset opplcering for alle elever kommer til uttrykk $i$ skolen, og av spesialpedagogens rolle $i$ denne sammenheng (Doktoravhandling). Universitetet i Oslo, Oslo.

Møller, J. (2009). School leadership in an age of accountability: Tensions between managerial and professional accountability. Fournal of Educational Change, 10(1), 37-46.

Nordahl, T. (2018). Inkluderende fellesskap for barn og unge Oslo: Kunnskapsdepartementet.

Rosenberg, M. (1977). Contextual dissonance effects: Nature and causes. Psychiatry: Fournal for the Study of Interpersonal Processes, 40(3), 205-217.

Rosenberg, M. (1979). Conceiving the self. New York: Basic Books.

Skaalvik, E. M. \& Skaalvik, S. (2017). Motivated for teaching? Associations with school goal structure, teacher self-efficacy, job satisfaction and emotional exhaustion. Teaching and Teacher Education, 67, 152-160.

Strauss, A. L. \& Corbin, J. M. (1998). Basics of qualitative research. Techniques and procedures for developing grounded theory (2. utg.). Thousand Oaks, CA: Sage Publications.

Tjora, A. (2013). Kvalitative forskningsmetoder i praksis (2. utg.). Oslo: Gyldendal Akademisk.

UNESCO (1994). The Salamanca statement and framework for action on special needs education. Hentet fra http:// www.unesco.org/education/pdf/SALAMA_E.PDF

Uthus, M. (2014). Spesialpedagogenes oppfatning av sin rolle $i$ en skole for alle. Idealer, Realiteter og belastninger (Doktoravhandling). Norges teknisk-naturvitenskapelige universitet, Trondheim.

Uthus, M. (2017a). Den inkluderende skolen. Muligheter og begrensninger. I M. Uthus (Red.), Elevenes psykiske helse $i$ skolen. Utdanning til å mestre egne liv (s. 130-154). Oslo: Gyldendal Akademisk.

Uthus, M. (2017b). Et helsefremmende inkluderingsbegrep. I M. Uthus (Red.), Elevenes psykiske helse $i$ skolen. Utdanning til å mestre egne liv (s. 157-185). Oslo: Gyldendal Akademisk.

Uthus, M. (2018a). Spesialpedagogikk for morgendagens skole - nye mål og ny mening. Spesialpedagogikk, $83(4), 16-24$.

Uthus, M. (2018b). Spesialpedagogikk - Gamle myter og nye muligheter. Spesialpedagogikk, 83(4), 30-39.

Utdanningsdirektoratet (2018a). Grunnskolens informasjonssystem. Hentet fra https:/gsi.udir.no/

Vedvik, K. O. (2018) GSI: Rekordmange elever på spesialskole. Utdanningsnytt.no. Hentet fra https://www. utdanningsnytt.no/nyheter/2018/desember/rekordmange-elever-pa-spesialskole/

Watson, J. (1985) Nursing: The Philosophy and Science of Caring. Boulder: University Press of Colorado.

Wendelborg, C. (2014). Fra barnehage til videregående skole. Veien ut av jevnaldermiljøet. I J. Tøssebro \& C. Wendelborg (Red.), Oppvekst med funksjonshemming. Familie, livsløp og overganger (s. 35-58). Oslo: Gyldendal Akademisk.

Wendelborg, C. (2017) Inkludering versus marginalisering. I M. Uthus (Red.), Elevenes psykiske helse $i$ skolen. Utdanning til å mestre egne liv (s. 110-129). Oslo: Gyldendal Akademisk.

Wigfield, A. \& Eccles, J. S. (1992). The development of achievement task values: A theoretical analysis. Developmental review, 12(3), 265-310.

Wigfield, A. \& Eccles, J. S. (2000). Expectancy Value Theory of Achievement Motivation. Contemporary Educational Psychology, 25(1), 68-81.

Zhang, D., Wang, Q., Losinski, M. \& Katsiyannis, A. (2014). An Examination of Preservice Teachers' Intentions to Pursue Careers in Special Education. Fournal of Teacher Education, 65(2), 156-171. 